\title{
Displaying knowledge in journalistic texts: A contrastive analysis of an evidential particle in Estonian and Finnish
}

\author{
MINNA JAAKOLA \\ University of Helsinki
}

\begin{abstract}
This paper examines the semantics of the Estonian and Finnish epistemic-evidential particles teatavasti and tiettävästi ('as is generally known' and 'as far as is known'). Based on newspaper data and focusing on textual and intersubjective meanings, this analysis adopts the Cognitive Grammar description of relational predicates. The comparison is based on the properties of the fact that is within the scope of the particle (knowledge that is specific or generic, conventionalised or non-conventionalised, and more or less irrefutable). Whereas the Finnish particle conveys a strong implication of reported knowledge, which often causes a message of slight hedging, the Estonian particle is used to mark the issue at hand as being certain. In addition, the information in Estonian is displayed as being accessible and shared to interlocutors. On a textual level, the characteristic feature of this Estonian particle is to mark a fact as the background information for a more topical element of the text. In contrast, the Finnish particle is often used for organising the different reported voices in a text.
\end{abstract}

Keywords: epistemic modality; evidential modality; relational predicate; intersubjectivity; Cognitive Grammar 


\section{Introduction}

As we use language - to chat, to write, to read - we constantly process the epistemic and evidential status of entities in terms of where they stand in relation to what we currently know. This paper studies construals of knowledge by focusing on the textual usages of lexemes that express knowing. The study compares a pair of Finnish and Estonian look-alike words, the modal particles teatavasti (Estonian) and tiettävästi (Finnish). According to dictionaries, these particles convey a rather similar epistemic-evidential meaning: they express the degree of certainty and factuality, and the degree of accessibility and conventionality of a specific knowledge.

These modal particles have been described similarly in dictionaries, and the Finnish-Estonian and Estonian-Finnish dictionaries organise the words in lists according to their possible translation equivalents in the other language. ${ }^{1}$ The definitions that are provided highlight the certainty and the sharedness of knowledge, the interlocutors' potential to know the fact at hand. For example, the Estonian teatavasti is defined as 'nagu teada, teadupoolest' (EKSS s.v teatavasti), 'as is generally known', 'as we (or) you know' (EI s.v. teatavasti). In comparison, according to the dictionaries, the Finnish tiettävästi means 'as far as is known / I know / we know [knew, have known]' (MOT English), and 'niin kuin asian (yleisesti) tiedetään, arvellaan t. uskotaan olevan, luultavasti' (PS s.v. tietty, MOT KS s.v. tiettävästi).

Morphologically, the words are passive present participles, including a verb stem (tea-/tiet- 'know-'), a passive marker (TA), a participle marker $(v A)$, and finally a derivational suffix -sti (corresponding to English suffix ' $-l y$ ' $).^{2}$ Syntactically, both are used as clause modifiers,

1 VSS s.v. teatavasti: 'kuten tiedetään, tiettävästi'. SSVS s.v. tiettävästi: 'kuuldavasti, teatavasti, nagu teada, teadupärast, teadupoolest, arvatavasti.

2 The formal differences are minimal. The root of the derivatives, the verb teadal tietää ('to know') dates back to the Balto-Fennic form ${ }^{\star}$ teetä- (Häkkinen 2004: s.v. tietää). The vowel combination ${ }^{\star} / e e /$ in the historical root has developed in Finnish as the diphthong /ie/ and in Estonian as the vowel combination /ea/. In Finnish, the 
functioning as markers of the interlocutor's mood or attitude. Both are particles - uninflected words that function as clause modifiers and that do not allow modifiers of their own (EKG II: $₫ 554,555,557$; VISK: $\$ 870,1000,1606)$.

Textually, however, these two words are used differently. For example, in news texts, as illustrated in example (1), the words tiettävästi and teatavasti are not semantic counterparts.

(1a) Estonian:

FC Levadia koosseis kordusmänguks Newcastle Unitediga [headline] FC Levadia Tallinna peatreener Tarmo Rüütli nimetas 18 mängija nimed, kes lendavad teisipäeva õhtul Inglismaale osalemaks 28. septembril toimuval UEFA karikasarja I ring kordusmängus Newcastle Unitediga.

$\rightarrow \quad$ 14. septembril Tallinnas peetud avamängu Levadia teatavasti kaotas 0:1. (http://sport.err.ee/index.php?0541103)

'FC Levadia players for the second leg against Newcastle United [headline]

The head coach of FC Levadia named the 18 players, who will fly next Tuesday evening to England to play on 28th September the second leg in the UEFA league's first qualifying round against Newcastle United.

$\rightarrow \quad$ The 14 of September match in Tallinn, as is generally/already known, Levadia lost $0: 1^{\prime}$

(1b) Finnish translation with tiettävästi:

14. syyskuuta Tallinnassa järjestetyn avauspelin Levadia tiettävästi hävisi 0:1

'The 14th of September match in Tallinn Levadia, as far as is known, lost 0:1'

The word tiettävästi in the translation (1b) changes the epistemic and evidential stance of the writer. If one interprets the Estonian teatavasti to

word form is based on a consonant stem (the root-final $/ t /$ ). Vowel harmony explains the back vowel / $\ddot{a} /$ in the passive marker TA and in the participle $v \mathrm{~A}$ that occur in the Finnish variant. Of course, it is not self-evident that the morphemes are the same in the synchronic sense. I will return to this question briefly in Section 5. 
be a full equivalent to the Finnish tiettävästi, the semantics of the translated clause would be 'there is something uncertain about the result of the match, or about the source of the information, so the writer does not fully commit to the exact number of goals'. In the context of a sport news report published on-line, this interpretation is un-expected; thus, one must find another way to translate the clause. This type of difference in meaning concerning modality leads to different textual and intersubjective functions, which all render the words more as false friends than as synonyms.

The main purpose of this paper is to present a contrastive analysis of two modal particles that belong to non-referential parts of speech. Modal utterances are meaningful not only by virtue of expressing the speaker's/writer's feelings about the state of affair, but also by construing intersubjectivity, the ways interlocutors relate to each other and to the speech situation (Verhagen 2005: 60). Modal particles are used to mark the stance of the speaker/writer, but equally importantly, they index the structuring of the ongoing context, the interlocutors' expectations towards each other, and their participation roles (e.g. Mushin 2001; Kärkkäinen 2003). As example (1) illustrates, a contrastive perspective may make the intersubjective and textual functions more observable, for example, by revealing contexts in which a specific word cannot be used. As for teatavasti and tiettävästi, contrastive analysis highlights the different mechanisms that writers use to exploit the aspects of knowing to functions that are intersubjective and textual and the way writers construe a reader's access to knowledge (concerning the contextual analysis of epistemic and evidential markers, see e.g., Chafe 1986; Mushin 2001; Nuyts 2001; Aikhenvald 2004 Chapter 10; Byloo etc. 2007; Celle 2011).

In the present analysis, I adopt the semantic theory of Cognitive Grammar and its concept of particles as relational predicates (Langacker 1987: 242-243; 2008: 116). According to this theoretical orientation, the meaning of a particle consists of a relation and the entities participating in it. The sides of a relation play a key role, and I will base my contrastive analysis on their properties. For the modal particles teatavasti and tiettävästi, the different types of knowledge are especially important. 
The outline of the paper is as follows. Section 2 presents the methods. Section 3 introduces the data, which consist of newspaper genres. The focus of Section 4 will be on the textual organisation and interactional orderings of a written language that involve the different usages of tiettävästi and teatavasti. Section 5 discusses the overall findings.

\section{Contrasting modal particles}

Epistemic modality is defined in this paper as marking the degree of confidence about a statement, which is an estimation of the likelihood that a certain state of affair is factual (see, e.g. Nuyts 2001: 21-22). Epistemic modality is often illustrated by the imagery of a scale running from certainty to impossibility, for example, as the continuum certain - probable - possible - uncertain - improbable - impossible (e.g. Nuyts 2001: 22; Kangasniemi 1992; VISK: $\$ 1556)$. In example (1), Estonian teatavasti marks the claim as being certain, whereas the Finnish tiettävästi expresses slight hedging, which implies that the ranking of the words differs within the scale.

My concept of the evidentiality adopts the broad definitions that evidential constructions express something about the evidence and source of a statement (see Chafe 1986: 262; Mushin 2001: 17-35). ${ }^{3}$ There are several ways for evidence to support a statement. For example, the knowledge may be quotative, second-hand, hearsay, sensory, inferred or assumed (Aikhenvald 2004: Chapter 2). The particles teatavasti and tiettävästi represent a special case of evidentials because they do not express how or where the information has been obtained. On the contrary, these particles express the non-specificity in relation to the source.

\footnotetext{
3 Aikhenvald (2004) provides a narrower definition of evidentiality as being a purely grammatical category that expresses a source of information. An example of such category would be the quotative modus in Estonian and Livonian (Aikhenvald 2004: 55; EKG I: $\$ 63$; Erelt 2002; Kehayov 2008). For the definitions and relationship between epistemic and evidential modality see, e.g. Chafe (1986); Nuyts (2001: 27-28); Kehayov (2009).
} 
They also indicate that the knowledge is not specific to one individual but is accessible to others, versus, for example, the derivatives that are formed using explicit person markers, which profile the knowledge of individuals: meie teada [we-GEN know-INF] and tietääksemme [knowINF-TRA-1PL.POSS].

The non-specificity is motivated by the composition of the words. They are derivatives from the cognitive verbs tietäa (Finnish) and teada (Estonian), which both mean 'to know' and both express propositional knowledge (e.g. Finnish tiedän, että 2 plus 2 on neljä, 'I know that 2 plus 2 is four'). Estonian teada is also used to express skill or know-how (EKSS s.v. teada gives it as a third meaning: Võoraid keeli on kasulik teada, 'it is useful to know foreing languages'). This usage is marginal in Finnish (tietää laulun sanat, 'to know the lyrics', but osata saksaa lit., 'can/know German'). (On the senses of epistemic verbs such as to know (Wierzbicka 1996).) In this respect, the most important aspect is nevertheless common, as the verbs tietäa and teada construe the act of knowing as a stative process and without reference to evidential sources or processes. In addition, the passive also plays a role in the evidential meaning of the particles. The passive in Finnish and in Estonian construe person reference, but the reference is open and will be defined from the context (Helasvuo \& Laitinen 2006; EKG II: \490; VISK: \$ 1331; Rajandi 1999; Remes 2009: 112, 114-116). As the derivatives teatavasti and tiettävästi are passive forms, they also indicate that the knowledge is displayed as shared in the sense that others may also have access to it.

The analysis in Section 4 adopts the Cognitive Grammar description of relational predicates (Langacker 1987: 242-243; 2008: 116). The modal particles in Finnish and Estonian are predicates whose schematic meaning is to evoke a relation between two entities. This is also compatible with the meaning of the derivational suffix -sti ('-ly'), which forms the adverbs and particles used for marking, for instance, manner, value, intensity and comment (VISK: $\$ 1002$; EKG I: $\$ 455$ ). The meaning of a relational predicate consists of a relation itself and the entities participating in it. In this case, the sides are the modal domains (epistemic/ 
evidential) that express a stance of the interlocutors (landmark), and the specific piece of knowledge within the scope of the particle (trajector, concerning the terms, see Langacker 1987: 231-236). For example, in the sports news text above (1), the statement Levadia kaotas 0:1, 'Levadia lost $0: 1$, serves as a trajector in a relation that the particle construes.

The properties of knowledge expressed within the trajector of the particle are essential to the meaning of that particle. These properties play a key role in the current analysis. In Section 4, a division of the different types of encyclopedic knowledge (Langacker 1987: 159-161; Evans \& Green 2006: 216-220) is exploited in describing the meaning of tiettävästi and teatavasti. An entity can be characterised as representing knowledge that may be generic or specific, intrinsic, characteristic, and conventional or non-conventional. The aforementioned types of knowledge are distinct, but they do overlap and can be described as operating along a continuum from, for instance, conventional to non-conventional knowledge and from generic to specific knowledge.

By generic knowledge, Langacker (1987: 159-161) refers to the information that applies to many instances of a certain category. Generic knowledge contrasts with specific knowledge that concerns individual instances of a category. For example, the generic knowledge relating to cars is that they will be destroyed if they crash into another car. A specific knowledge, in contrast, would be facts concerning the great pile-up of cars in an accident in Helsinki on 3 February 2012. According to teatavasti and tiettävästi, the relevant dimensions are specific versus generic knowledge, whereas intrinsic and characteristic knowledge falls within the sphere of generic and specific knowledge and are not prominent in this data. Conventional knowledge is information that is widely known and shared between the members of a community. Furthermore, specific and general facts can be either conventional or non-conventional, and different speech communities can assume different knowledge as being conventional.

As analytical tools, continuums and scales provide a practical way to structure the data. The grouping of examples in this study is based on 
the properties of a trajector (the fact within the scope of the particle). Further, the comparison of Estonian and Finnish examples is based predominantly on the division of the trajectors between knowledge that is specific (Section 4.1) and generic (Section 4.2). However, conventionality functions on a different level, as specific and general facts can be either conventional or non-conventional. Yet in my data, entities representing generic knowledge are also often conventional in the speech community. In addition to the aforementioned aspects of knowledge that is specific versus generic and conventional versus non-conventional, the data also highlight another relevant feature of a trajector that affects the interpretation of the particles: especially general facts may also be irrefutably certain, factual facts in any circumstances. This type of absolute factuality of facts can be based on, for example, physical laws and can become expressed by the linguistic form of a proverb (see Section 4.2).

\section{The data}

The words teatavast $i$ ja tiettävästi are specifically elements of written language. In written genres, the Estonian teatavasti has a wider variation: while the Finnish word is almost exclusively used in newspaper texts and in similar expository text types, and it occurs extremely rarely in corpora of other genres, the Estonian variant also exists in other text types (Jaakola 2011: 517; Eesti kirjakeele sagedussõnastik). This study will concentrate on the media that are common to both words, the newspaper genre texts. The analysis of the Finnish tiettävästi is based mainly on the data collected from The Language Bank of Finland (four newspaper subcorpora in the Finnish Text Collection). The Estonian data are collected from the Internet archive of two Estonian newspapers, the Postimees and the Õhtuleht. Table 1 shows the number of tiettävästi and teatavasti in the data. 
TABLE 1. The data: number of tiettävästi and teatavasti in the selected newspaper sample

\begin{tabular}{|c|c|c|c|}
\hline Finnish newspapers & tiettävästi & Estonian newspapers & teatavasti \\
\hline Karjalainen 1995 & 188 & \multirow{2}{*}{$\begin{array}{l}\text { Postimees } \\
(1.1 .-1.8 .2007)\end{array}$} & \multirow{2}{*}{72} \\
\hline Aamulehti 1995 & 164 & & \\
\hline Demari 1995 & 101 & \multirow{2}{*}{$\begin{array}{l}\text { Õhtuleht } \\
(1.1 .-30.4 .2011)\end{array}$} & \multirow{2}{*}{104} \\
\hline Iltalehti 1996 & 50 & & \\
\hline Total & 503 & & 186 \\
\hline
\end{tabular}

The two Estonian Internet sites include most of the articles published in print as well as some additional text, mostly columns and short news texts. ${ }^{4}$ These data are appropriate for the present study because they are sufficiently diverse and enable the relevant textual functions to be defined for comparison. Moreover, the central features in newspaper genres are evidentiality, conventionality and the construal of shared knowledge. Newspaper texts represent a fairly wide range of the different text types (for example news, news reports, feature stories, columns, and quizzes), and consequently, the core functions of both lexemes will emerge. Indeed the versatility of the Estonian data compensates rather well for the lack of literary genres, which of course would be needed if the aim were to provide a full description of the Estonian teatavasti. A complete description of the polysemy of the words would also require a sample of more dialogical discourses (for example chat room data), but this is beyond the scope of the present analysis.

4 The Corpus of Estonian Literary Language (http://www.cl.ut.ee/korpused/baaskorpus/ (27.06.2012) would provide interesting data collected from different genres. However, the user interface is not ideal for a contextual analysis, as the complete texts are not easily visible. In addition, by using data from the "Postimees" and the "Õhtuleht", it is relatively easy to check factors such as factuality, newness, and the conventionality of the issues. 


\section{The analysis}

\subsection{Specific knowledge}

Both lexemes occur most often in the data in clauses where there is specific knowledge within their scope. However, these types of clauses work differently in Finnish and in Estonian, hence the modal meanings of the particles differ. Examples (2) and (3) illustrate this. In Finnish, the most typical context for the particle tiettävästi is news texts, and it often occurs in texts that introduce some type of accident or catastrophe. In Estonian, the particle likewise occurs often in news texts, although its function is different. The most typical text type in my data for the Estonian teatavasti in news texts occurs in short sport reports (82 out of 186).

(2) Finnish:

Tiettävästi kukaan ei kuollut eikä loukkaantunut räjähdyksessä, mutta ainakin osa asukkaista jäi loukkuun huoneistoihinsa. (Aamu1995)

'Tiettävästi no one died or was injured in the explosion, but at least some of the residents were trapped in their flats.

(3) Estonian:

Üllatavalt nõrgalt esinesid meie põhjanaabrid, kelle meeskond ja naiskond kukkusid tulevaks aastaks B-tugevusgruppi. Teatavasti võitsid Soome mehed Torino olümpial hõbemedali. (Postimees 06.12.2007)

'Our northern neighbours played surprisingly weakly, since their men's and women's teams fell to the Category B for the next year. Teatavasti Finnish men won the silver in the Toronto Olympics.'

In Finnish news texts, the trajector of the particle tiettävästi often contains a fact concerning a number of victims, the extent of damages, etc. ${ }^{5}$ Here the information presented in a clause is specific and new to the reader. Nonetheless, the particle tiettävästi displays the knowledge also being as potentially accessible to others in addition to the writer by marking explicitly that the knowledge has a source. In other words, the

5 For example, in $1 / 3$ of the occurences the trajector includes some kind of an extreme value (e.g. first, oldest), number or extent. 
Finnish tiettävästi creates a strong implication of marking the information status as reported speech, and would express the message of 'as far as is known based on the information at hand. This interpretation is crucial in news texts. In fact, this particle is conventionalised in these texts to imply that the second-hand accounts that the newspaper is relying on are appropriate and reliable. The intersubjective function of the word is to construe a reading position to a knowing reader who understands how a newspaper obtains its information. In this respect, the particle is used as an assurance of the fact (Kakkuri-Knuuttila 1998: 256). This means that it is a conventionalised feature of the genre used for construing the reliability of the news text and its facts; in this function the word tiettävästi is even explicitly mentioned in journalism text books (Kuutti \& Puro 1998; for features of the genre of Finnish news texts see, Saukkonen 2001: 156-157).

In the Estonian example (2), the implication of reported, secondhand knowledge is not expressed. In Estonian, reported speech meaning is created by other constructions (such as the phrase praegustel andmetel, 'by current sources'), and also by the grammatical evidential modus, the quotative verb form (such as ta olevat tulnud, 'reportedly, she has come') (Erelt 2002: 94; Metslang \& Pajusalu 2002). The Estonian teatavasti profiles a meaning of shared knowledge, and the meaning is present even with quite specific and less conventional information in news texts. By using this particle, a writer suggests that the reader may know the fact or has access to that fact. There are different justifications for such an implication, but one of the most often exploited one in the data is a temporal organisation to which a writer refers. In other words, the state of affairs referred to by the trajector of teatavasti has, in real life, occurred earlier and has also been introduced in the media earlier, as examples (1) and (3) illustrate. It is important to note that the teatavasti-clause often also includes a temporal adverb or another reference point that allows one to anchor the issue in the past.

The strategy of displaying knowledge as shared is exploited on a textual level in many ways. First, the teatavasti-clause can function as a 
reminder, (as in examples 3 and 4). It may also be used as a reason, as in example (5), where the teatavasti-clause is used as an explanation for the claim made in the interviewee's next sentence.

(4) Estonian:

Arutuse all oli kooliõpilaste toidu hind, mis kehtestati Tallinna linnavalitsuse määrusega 1999. aastal ja mis kehtib siiani. Teatavasti on koolitoit põhikooli õpilastele tasuta. Tallinna linn lisab riigi antud kümnele kroonile neli krooni juurde. (Postimees 27.9.2007)

'Under discussion was the price of the students' meal, which was approved by the Tallinn Town Board Order in 1999 and which is still in effect. Teatavasti the meal is free for the students attending primary and secondary schools. The city of Tallinn supports the government's ten crone with four crones.'

(5) Estonian:

"Mulle näib, et kogenud poliitik on täitsa sassi läinud," teatas Atonen. "Eesti Vabariigis ei muutu teatavasti 1. jaanuarist ükski käibemaksumäär. Seega käibemaksu tõusust rääkides Edgar Savisaar lihtsalt kas eksib või valetab teadlikult." (Postimees 11.12.2007)

"Seems to me that the experienced politician is totally mistaken", said Atonen. "In the Estonian Republic teatavasti on the first of January, no turnover tax will change. Thus, when Edgar Savisaar talks about turnover tax increase, he either errs or lies knowingly."

The teatavasti-clauses serve in texts as background information, and the specific functions of the clause (reminding, reasoning or otherwise commenting) are elaborations that have a more schematic textual pattern of foregrounded versus backgrounded information. This explains the interpretation of accessible knowledge and in this sense shared knowledge even when the information at hand seems to be conventionalised only for a highly restricted audience. This is illustrated well in example (6), which is a quiz that appears on a newspaper site.

(6) Estonian:

Esimene olümpiamängude kuldmedal toodi Eestisse teatavasti 1920. aastal Antwerpenist. Esimeseks eestlasest olümpiavõitjaks oli tõstja 
Alfred Neuland. Samadelt mängudelt toodi Eestisse ka kaks hõbemedalit. Kes need võitsid ja mis alal? (Postimees 1.8.2006)

'Estonia won the first Olympic gold medal teatavasti in the year 1920 in Antwerp. The first Estonian Olympic winner was the weightlifter Alfred Neuland. In the same Olympic games Estonia also won two silver medals. Who won these, and what was the sport?'

The first sentence in which teatavasti occurs introduces the topic (Olympic games) and provides a detailed fact (the first gold medal for Estonia). This fact functions as the background for the question formed by the final clause, which is the foregrounded element of the quiz. The information in the first sentence is also explicitly offered to the reader as shared by using the particle teatavasti. In addition, this particle overtly marks the foregrounded/backgrounded organisation of the text (as it also does in example 1). Thus, the piece of knowledge is also displayed as shared for the sake of the textual level organisation: for instance, to mark the knowledge as introductory information and not as the topic of the text or paragraph.

In these contexts, the Estonian particle teatavasti could often be translated into Finnish by the clitic- $h A n$, which also carries the meaning of shared knowledge (Hakulinen 2001: 65; Lehtinen 2012). In declarative sentences, this meaning may function as a reminder or reasoning (c.f. Hakulinen 2001: 64-67; VISK: $₫ 830$ ). Of course, the particle $-h A n$ has meanings that are not included in the semantics of the particle teatavasti. Another option for Finnish translations would be kuten tiedetään, 'as is known' (as in example 6), or to not mark the evidential status lexically at all, whereas tiettävästi would convey semantic features that are not present in the source text.

The crucial difference between tiettävästi and teatavasti lies in their construals of epistemic modality, which may cause problems for the translations of texts such as the ones mentioned above. While marking a given fact as a reported speech, and in this respect a fact that is relatively reliable, the Finnish tiettävästi also evokes the interpretation that the writer does not fully commit her/himself to the factuality of that 
fact, but instead adds a slight hedge. In newspaper contexts, this means that the writer admits that some new information might change some detail of the fact. This type of interpretation (the fact being highly probable but not $100 \%$ certain) is clearly observable in clauses where the particle has within its scope some extreme value, an amount, a price, a date, a location, etc.

(7) Finnish:

Syksyllä aloitettu koulutus on tiettävästi ainutlaatuista koko maailmassa. (Karjalainen 1995)

'Schooling started in the autumn is tiettävästi unique to the whole world.'

In this example, the whole sentence expresses an entity (new schooling) and a characteristic superlative attribute (its outmost rarity). The attribute specifically is within the scope of the particle, and the epistemic stance is oriented towards the certainty of the superlativity. This particle is thus used in a rethorical pattern, where the writer commits herself to the evaluation of the rare nature of the certainty, but hedges whether that rarity it absolute.

Using the Finnish particle tiettävästi to hedge is motivated by the implication of reported knowledge, which by its very nature is based on the non-specificity of the information source: the particle does not explain how the information comes about, rather it indicates that this information can be shared and that it is not specific to the writer alone. The central textual function of the particle is also related to the implication of second-hand information. As a non-specific evidential, it can be used to imply a possible change in the perspective or to express opposing voices within the reported speech. This meaning emerges especially when a source is explicitly marked in some near proximity of the particle teatavasti. Example (8), a news text on the economy, which concerns a company merger, illustrates how this particle is used to designate a different information source than in the previous sentence. 
(8) Finnish:

Heinäkuussa fuusiohuhut saivat taas vauhtia, kun Merita Pankki myi kansainvälisille sijoittajille ison siivun Kymmenen osakkeita. Meritasta tiedotettiin, ettei asialla ole mitään tekemistä mahdollisissa metsäalan järjestelyissä. Tiettävästi Kymmenen ja Repolan omistajat olivat asian kimpussa kesähelteilläkin. (Aamulehti 1995)

'In July rumours about a merger started to gather momentum when The Merita Bank sold a large number of Kymmene shares to international investors. Merita announced that this had nothing to do with the possible arrangement in forestry. Tiettävästi the owners of Kymmene and Repola were at work on the matter even during the summer.'

In this example, evidential meanings are construed by the expressions referring to the rumours in the first sentence (fuusiohuhut, 'rumours about merger') and to the specific source (Meritasta tiedotettiin, 'by Merita information was given'), and by the tiettävästi-clause in the last sentence. Without that particle, the source of the last sentence would be interpreted to be the Merita Bank. The particle puts an end to the phase where the announcement by Merita has been reported and explicitly designates the information as originating from some other source. The particle tiettävästi can even imply a rumour. These meanings - features of hedging, reported knowledge or rumour - are what cause the incompatibility between teatavasti and tiettävästi.

\subsection{Generic and conventional knowledge}

The Estonian particle teatavasti also occurs easily with generic knowledge, and its meaning is similar to the usages with a specific knowledge (see above). The core meaning of the Estonian particle as is generally known' is also compatible with generic knowledge (9) and as well for clauses expressing generic and highly conventional knowledge (10).

(9) Estonian:

Maailma ajaveebindusest kirjutav ajaveeb The Blog Herald juhtis hiljuti tähelepanu vastutusele, mida blogipidajad tunnetama peavad. 
Sõnavabadus ei ole teatavasti õigus kirjutada seda, mida sülg suhu toob. See on vastutamine oma sõnade pärast. (Postimees 19.11.2007) 'The Blog Herald, which writes about the weblogs of the world, placed the liabilities of bloggers in the spotlight. Freedom of expression is not teatavasti a right to write whatever enters your head. It is to assume responsibility for your own actions.'

(10) Estonian:

Teatavasti peitub saatan detailides. Millised detailid on jäänud veel kokku leppimata? (Postimees 14.9.2007)

'Teatavasti devil is in the details. Which details are not yet agreed on?'

In example (9), the topic is freedom of expression, and it is generic knowledge concerning one concept and its values. Example (10) contains a teatavasti-clause that consists of a highly conventional and almost universal, proverb-like statement. In the example, the motivation for the usage of this particle is to explicitly mark the knowledge as conventional. As importantly, on a textual level, the teatavasti-clause marks the utterance as a reminder or as an explanation.

A reminder of this type may often occur in a rhetorical pattern which expresses some type of a contrast or comparison, as in example (9). This pattern involves two (or more) issues that are compared or contrasted. In example (11), the first part characterises how freedom of expression should not occur, and this position is marked by using the particle teatavasti. The next sentence, the second part of the contrastive pattern, shows the correct interpretation for the freedom of expression as the writer envisions it. The presence of this particle emphasises the contrast, and by underlining the conventional status of the claim, the writer strongly convinces the reader to accept and to share that opinion. The reminding teatavasti-clauses may function as either a first part or a second part of a contrastive pattern, and especially in the pre-position, the interpretation of backgrounding information is easily activated, as shown in examples (10) and (11). ${ }^{6}$ Again, the meaning in these usages

\footnotetext{
6 The contrastive pattern is a general rhetorical figure, and the teatavasti-clause position it has in it in relation to foreground/background asymmetries also depends
} 
can often be translated into Finnish by the clitic -han, or by phrases such as kuten tiedetään, kuten tunnettua ('as we all know').

In newspaper data, the Finnish tiettävästi occurs rarely in connection with generic knowledge, and especially rarely with conventional knowledge. One explanation for that division is that when imparting conventional knowledge, tiettävästi gives rise to some kind of polyphonic voice in the text. It is often used as one of the markers of readings that are humorous, ironic or otherwise affective, and the more indisputable the fact is, the more affective the readings are concerning this particle. To illustrate these polyphonic usages of the Finnish particle, I will conclude this section by citing an example from an internet discussion forum. Example (11) is an excerpt of a comment that is part of a humorous and rambling discussion concerning the different and snobbish pronunciation styles.

(11) Finnish:

Mistä voit tietää, miten latinaa oikeasti pitäisi lausua? Tiettävästi kenelläkään ei ole Ciceron tai Julius-keisarin puheita nauhalla. --Ainoa valtio, jossa latina on virallisena kielenä, on Vatikaani, eikä tiettävästi kukaan sielläkään puhu sitä äidinkielenään. Latinaa äidinkielenään puhuvalla kai pitäisi olla Vatikaanissa asuva nunna äitinään, mikä tekee asiasta hieman monimutkaisen. (SF.Net., read 30.4.2007) 'How it is possible that you know how Latin should really be pronounced? Tiettävästi no-one has Cicero's or Julius Caesar's speeches on tape. --- The only state where Latin is official language is the Vatican, and even there tiettävästi no one speaks it as his or her mother tongue. If one had Latin as a mother tongue, his or her mother should be a nun living in the Vatican, which makes things quite complicated.'

As we can see, the comment above is written in an ironic style. The first tiettävästi-clause includes a fact that is true: Cicero and Julius Caesar lived long before the time of tape recorders. What the second tiettävästiclause expresses is somewhat more complicated, but if a reader follows

on other aspects, especially the larger thematic structure of a paragraph. The contrastive use of teatavasti is also not restricted to generic knowledge. 
the writer's reasoning, the state of affairs is true - that the inhabitants of the Vatican do not have Latin as their mother tongue (if a reader accepts the writer's definition of a mother tongue that is provided in the next sentence). Ironic interpretations have been demonstrated to be dependent on incoherence (Rahtu 2011), and the two tiettävästi-clauses are indeed internally incoherent. In the excerpt above, this incoherence is based on two different epistemic values: an indisputable fact and a hedge, tiettävästi. As seen above, the meaning of the hedge conveyed by this particle is strongly based on the implication of second-hand and thus on the slightly questionable information, 'as much as is known based on the information at hand'. In modern Finnish, neutral readings ('as is generally known') are rather difficult to find with generic knowledge and especially with highly conventional knowledge.

The next section summarises the findings arising from the comparison of teatavasti and tiettävästi. The section also discusses briefly the differences and similarities of these two lexemes in the light of semantics and morphological composition of the derivatives.

\section{Differently shared knowledge}

The Finnish tiettävästi appears frequently in news texts, where what is within its scope is a piece of very specific, non-conventional knowledge. In news texts, this particle conveys a strong implication of reported knowledge; both the reported information meaning and the more schematic second-hand information meaning serve as a basis for using this word as a hedge for an argument. The meaning of tiettävästi is approximately 'as far as is known, based on the information at hand', and only rarely is it 'as is, with high likelihood of being generally known.' This particle has a conventionalised usage in news texts, where it is used to

\footnotetext{
7 For some reason, PS [Dictionary of Contemporary Finnish, s.v. tietty] does not mention the reported meaning (whereas its antecedent, the NS does). The PS provides the definitions 'niin kuin asian (yleisesti) tiedetään, arvellaan t. uskotaan olevan, luultavasti' [as is (generally) known, supposed or believed to be; probably]. The EKSS
} 
imply the reliability of sources and, in this respect, the particle is also used to confirm the truthfulness of the fact. Furthermore, in news texts the particle is used to construe a role of a knowing reader who understands how a newspaper obtains its information. Some Estonian translation equivalents in news texts would be praegustel andmetel ('by current sources'), and at least in some contextes some would also be the quotative modus referring to reported speech. In contrast, the Finnish tiettävästi occurs quite rarely with generic knowledge and rarely with highly conventional information. Such contexts are normally more polyphonic, and tiettävästi serves as a trigger for affective interpretations. In such contexts, the more indisputable the fact is, the more affective the readings are. On a textual level, the Finnish tiettävästi is used for organising the different reported voices in a text.

The Estonian word teatavasti, on the contrary, occurs with a wider variety of text types, and it is as easily used to mark specific and generic knowledge. The Estonian teatavasti is used to mark something that is certain, which would approximately convey the meaning 'as is generally known, as we all know', and it carries no implication of reported speech and no feature reflecting the uncertainty of the writer. Thus, when it also occurs with irrefutable knowledge, it does not itself cause readings that are affective, ironic or humorous.

In addition, the Estonian teatavasti explicitly marks that the fact is offered as being shared, despite the level of conventionality. On a textual level, this sharedness is exploited in many ways, but the common feature is to use the word to mark a fact as the background information for a more topical element of the text. The best illustration of this in Finnish translations would often be the clitic - $h A n$ (see 4.1). Another option would be the phrase kuten tiedetään ('as we all know') in contexts that emphasise the sharedness. In some cases, an easy solution perhaps would be to translate into Finnish without using an explicit marker for shared knowledge. However, this is a preliminary remark, and more

[Dictionary of Contemporary Estonian, s.v. teatavasti] defines the word faithfully as 'nagu teada, teadupoolest' [as is known]. 
contrastive research is needed concerning the evidential strategies adopted at the textual level in Finnish and Estonian, to determine whether, for example, news texts differ in how overtly the accessibility and sharedness of knowledge are marked.

The aforementioned differences in meaning make the words rather incapable of functioning as translation equivalents. To my knowledge, the pair tiettävästi-teatavasti has not been defined as being false friends, i.e. words that look similar, but differ in meaning ("valesõbrad", “riskisanat”) (Laalo 1992; Alvre \& Vodja 1993; Alvre 1995).

The meaning aspect of displaying shared knowledge is somewhat motivated by the morphological composition of the derivatives. The words are particles in the passive present-participle forms with the morphemes $T A+v(A)$. As mentioned in Section 2, the meaning of a verb stem produces the derivatives teatavasti and tiettävästi to mark nonspecific evidentiality. In addition, the passive in Finnish and Estonian conveys an open reference to person that becomes specified from the context.

As for Estonian teatavasti, the morphological motivation for marking knowledge as being accessible and shared is perhaps more transparent than its Finnish counterpart, and this is best illustrated by focusing on the passive participle stem teatav-/tiettävä-. In Estonian, the adjective teatav also has the lexicalised meaning of 'certain', for example, on olemas üks teatav raamat, 'there is a certain book'. This adjective is used to denote the common focus of attention in a speech situation to express that an entity is identifiable and in this respect, shared by the interlocutors. As described above, this meaning corresponds to the meaning of the particle teatavasti.

In contrast, the Finnish tiettävästi is more opaque, since the adjective tiettävä, formed with a consonant stem, is marginal in contemporary Finnish. A parallel form, which is based on the vowel stem, tiedettävä, may occur rarely in the syntactic position of a modifying adjective. Furthermore, different modal interpretations are possible in a modifier position, for example, tiedettävä asia, 'a thing that should 
know or is desirable to know. Typically, that vowel stem form is used as a part of a construction expressing obligation and necessity (e.g. Sinun on tiedettävä mihin rahat menevät, 'You must know where the money goes'). (Pekkarinen 2011: 14.) In contrast, the Estonian TAV-participle expresses temporal simultaneity and its modal meaning is restricted to general possibility. (Concerning the TAV $(A)$-participle, see EKG II: $\S 625$; VISK: $\$$ 524; Pekkarinen 2011: 17. $)^{8}$

\section{Conclusions}

Modal particles raise intriguing questions concerning the methodology of contrastive research on non-referential elements. As regards nouns and verbs, the extensional approach as well as the different production tests have produced interesting results (see, e.g. Majid et al. 2007; Taylor 2007). However, analyses of the non-referential elements of language that require textual and interactional focusing constitute an area in contrastive and typological research that has not been studied extensively (see, e.g. Aikhenvald 2004: Chapter 10). In this respect, a coherent semantic theory and detailed analytical tools provide a solid basis for comparisons. On the other hand, studies of the indexical elements in any linguistic field make use of contrastive studies, as contrastive methodologies may make intersubjective and textual meanings more observable, for example, by indicating problems in translation options. For instance, more contrastive research is needed between Estonian and Finnish concerning the textual level evidential strategies used in these languages. As for teatavasti and tiettävästi, contrastive analysis highlights the different mechanisms that writers exploit in the sharedness of knowledge

8 For a detailed comparison, the division of the suffixes -sti and -lt(i) in Estonian and Finnish should also be taken into consideration. For example, the most productive adverbial suffix in Estonian is the -lt (EKG I: $\$ 453$ ), but it is interesting that a sample of the epistemic TAV particles is formed by the -sti (e.g. kuuldavasti 'reportedly', nähtavasti 'apparently', oletatavasti 'supposedly'). The particle teatavalt is a synonym of the teatavasti that is marginal and stylistically marked (EKSS s.v. teatavalt). 
on the intersubjective and textual levels. In addition, contrastive analysis illustrates the different language-specific motivations for the meaning of these particles in relation to the different paradigmatic and syntagmatic levels.

\section{Acknowledgements}

I warmly thank Heete Sahkai for discussions concerning the polysemy of the Estonian teatavasti. I also thank the two anonymous referees for their valuable comments.

\section{Abbreviations}

$\begin{array}{ll}\text { GEN } & \text { genitive } \\ \text { INF } & \text { infinitive } \\ \text { PL } & \text { plural } \\ \text { POSS } & \text { possessive suffix } \\ \text { TRA } & \text { translative }\end{array}$

\section{Data sources}

Aamulehti 1995. Demari 1995. Iltalehti 1996. Karjalainen1995. - The Language Bank of Finland. Finnish Text Collection. Compiled by the The Department of General Linguistics University of Helsinki, The University of Joensuu, Research Insitute for the languages of Finland, and CSC - Scientific Computing Ltd. Available through CSC, $\underline{\text { http://ww.csc.fi. }}$

Postimees. http://www.postimees.ee/ (1.1.2007-1.8.2007).

Õhtuleht. http://www.ohtuleht.ee/ (1.1.2011-30.4.2011).

\section{References}

Aikhenvald, Alexandra Y. 2004. Evidentiality. Oxford: Oxford University Press. Alvre, Paul 1995. Suomen sanontoja virolaisine vastineineen. [Finnish Expressions and their Estonian Counterparts.] Felix Vakk, Vilma Parbo (Eds.). Tallinn: Valgus. 
Alvre, Paul, Raul Vodja 1993. Pulma poikineen. Virolais-suomalainen vertailusanakirja. [Estonian-Finnish Comparative Lexicon.] Helsinki: WSOY.

Byloo, Pieter, Richard Kastein, Jan Nuyts 2007. On certainly and zeker. - Mike Hannay, Gerard J. Steen (Eds.). Structural-Functional Studies in English Grammar. Amsterdam: John Benjamins, 37-57.

Celle, Agnès 2011. The intersubjective function of modal adverbs. A contrastive English-French study of adverbs in journalistic discourse. - Karin Aijmer (Ed.). Contrastive Pragmatics. Amsterdam: John Benjamins, 23-36.

Chafe, Wallace 1986. Evidentiality in English conversation and academic writing. - Wallace Chafe, Johanna Nichols (Eds.). Evidentiality: The Linguistic Coding of Epistemology. Norwood, NJ: Ablex, 261-272.

Eesti kirjakeele sagedussõnastik. [Estonian Frequency Dictionary.] http://www. cl.ut.ee/ressursid/sagedused/ (29.2.2012).

EI = Eesti-inglise sõnaraamat. [Estonian-English Dictionary.] 2006. Tallinn: Estonian Academy of Sciences.

EKG I = Mati Erelt, Reet Kasik, Helle Metslang, Henno Rajandi, Kristiina Ross, Henn Saari, Kaja Tael, Silvi Vare 1995. Eesti keele grammatika I. Morfoloogia. Sõnamoodustus. [Estonian Grammar I. Morphology. Word formation.] Tallinn: Eesti Teaduste Akadeemia Keele ja Kirjanduse Instituut.

EKG II = Mati Erelt, Reet Kasik, Helle Metslang, Henno Rajandi, Kristiina Ross, Henn Saari, Kaja Tael, Silvi Vare 1993. Eesti keele grammatika II. Süntaks. [Estonian Grammar II. Syntax.] Tallinn: Eesti Teaduste Akadeemia Keele ja Kirjanduse Instituut.

EKSS = Eesti kirjakeele seletussõnaraamat I-VIII. [Defining Dictionary of Standard Estonian.] 1988-2007. Tallinn: Eesti Keele Instituut.

Erelt, Mati 2002. Evidentiality in Estonian and some other languages. Introductionary remarks. - Linguistica Uralica 38 (2), 91-97.

Evans, Vyvyan, Melanie Green 2006. Cognitive Linguistics. An Introduction. Edinburgh: Edinburgh University Press.

Hakulinen, Auli 2001 [1976]. Liitepartikkelin -han/-hän syntaksia ja pragmatiikkaa. [On the syntax and pragmatics of the clitic particle - $h A n$.] - Lea Laitinen, Pirkko Nuolijärvi, Marja-Leena Sorjonen, Maria Vilkuna (Toim.). Lukemisto. Kirjoituksia kolmelta vuosikymmeneltä. Helsinki: Finnish Literature Society, 44-90.

Helasvuo, Marja-Liisa, Lea Laitinen 2006. Person in Finnish: paradigmatic and syntagmatic relations in interaction. - Marja-Liisa Helasvuo, Lyle Campbell (Eds.). Grammar from the Human Perspective: Case, Space and Person in Finnish. Amsterdam: John Benjamins, 173-208. 
Häkkinen, Kaisa 2004. Nykysuomen etymologinen sanakirja. [Etymological Dictionary of Modern Finnish.] Helsinki: WSOY.

Jaakola, Minna 2011. Epäspesifi evidentiaali. Nykysuomen tiettävästi. [The nonspecific evidential: the word tiettävästi as far as is known' in contemporary Finnish.] - Virittäjä 115 (4), 515-541.

Kakkuri-Knuttila, Marja-Liisa 1998. Retoriikka. - Kakkuri-Knuuttila, Marja-Liisa (Toim.). Argumentti ja kritiikki: lukemisen, keskustelun ja vakuuttamisen taidot. Helsinki: Gaudeamus, 233-272.

Kangasniemi, Heikki 1992. Modal Expressions in Finnish. Helsinki: Finnish Literature Society.

Kehayov, Petar 2008. An Areal-Typological Perspective to Evidentiality: The Cases of the Balkan and Baltic Linguistic Areas. Dissertationes linguisticae Universitatis Tartuensis 10. Tartu: University of Tartu

Kehayov, Petar 2009. Interactions between grammatical evidentials and lexical markers of epistemicity and evidentiality: A case-study of Bulgarian and Estonian. - Vladimir Plungian, Björn Wiemer (Hrsg.). Lexikalische Evidenzialitäts-Marker in slavischen Sprachen. Wiener Slawistischer Almanach, Sonderband 72. München-Wien: Otto Sagner, 165-201.

Kuutti, Heikki, Jukka-Pekka Puro 1998. Mediasanasto. [Media Lexicon.] Jyväskylä: Atena.

Kärkkäinen, Elise 2003. Epistemic Stance in English Conversation. Amsterdam: John Benjamins.

Laalo, Klaus 1992. Huvitav lugu - kiinnostava juttu. Suomen ja viron välinen sanaston riskiryhmä ja sen taustaa. [Finnish and Estonian Risk Words.] Helsinki: Finnish Literature Society.

Langacker, Ronald W. 1987. Foundations of Cognitive Grammar I. Theoretical Prerequisites. Stanford: Stanford University Press.

Langacker, Ronald W. 2008. Cognitive Grammar. A Basic Introduction. New York: Oxford University Press.

Lehtinen, Marjukka 2012. Episteemisen auktoriteetin ja yhteisen ymmärryksen konstruointi kokouskeskustelussa. Fokuksessa - $h A n$-lausumat. [Construing Epistemic Authority and Shared Understanding In Meeting Talk. A Focus on Utterances Containing The Finnish Clitic Particle - $h A n$.] Aalto University publication series. Doctoral dissertations 27. Helsinki: Aalto University.

Majid, Asifa, Marianne Gullberg, Miriam van Staden, Melissa Bowerman 2007. How similar are semantic categories in closely related languages? A com- 
parison of cutting and breaking in four Germanic languages. - Cognitive Linguistics 18 (2), 179-194. http://dx.doi.org/10.1515/COG.2007.005

Metslang, Helle, Karl Pajusalu 2002. Evidentiality in South Estonian. - Linguistica Uralica 38 (2), 98-109.

MOT English = MOT Finnish-English Dictionary 5.0. Kielikone Ltd.'s series of MOT dictionaries. Research Institute for the Languages of Finland and Kielikone Ltd 2008.

MOT KS = MOT Kielitoimiston sanakirja 2.0. [The New Dictionary of Modern Finnish.] Kielikone Ltd.'s series of MOT dictionaries. Research Institute for the Languages of Finland and Kielikone Ltd 2008.

Mushin, Ilana 2001. Evidentiality and Epistemological Stance. Narrative Retelling. Amsterdam: John Benjamins.

NS = Nykysuomen sanakirja. [Dictionary of Contemporary Finnish.] 1951-1961. Helsinki: WSOY.

Nuyts, Jan 2001. Epistemic Modality, Language, and Conceptualization. A Cognitive-Pragmatic Perspective. Amsterdam: John Benjamins.

Pekkarinen, Heli 2011. Monikasvoinen TAVA-partisiippi: Tutkimus suomen TAVA-partisiipin käyttökonteksteista ja verbiliittojen kieliopillistumisesta. [The Multifaceted Passive Present Participle in Finnish.] University of Helsinki, Faculty of Arts, Department of Finnish, Finno-Ugrian and Scandinavian Studies. http://urn.fi/URN:ISBN:978-952-10-6965-9 (29.2.2012).

PS = Suomen kielen perussanakirja I-III. [Basic Dictionary of Finnish Language.] 1990-1994. Helsinki: Research Institute for the Languages of Finland.

Rahtu, Toini 2011. Irony and (in)coherence: interpreting irony using reader responses to texts. - Text and Talk 31 (3), 335-354. http://dx.doi.org/10.1515/ text.2011.015

Rajandi, Henn 1999 [1968]. Eesti impersonaali ja passiivi süntaks. [The Syntax of the Estonian Impersonal and Passive.] Tallinn: Eesti Keele Instituut.

Remes, Hannu 2009. Muodot kontrastissa. Suomen ja viron vertailevaa taivutusmorfologiaa. [Forms in Contrast. A Contrastive Study of Inflectional Morphology in Finnish and Estonian.] Acta Universitatis Ouluensis Humaniora B 90. Oulu: University of Oulu.

Saukkonen, Pauli 2001. Maailman hahmottaminen teksteinä. [Structuring the World as Texts.] Helsinki: Yliopistopaino.

SVSS $=$ Suomi-viro-suursanakirja I-II. [Complete Finnish-Estonian Dictionary.] 2003. Tallinn: Research Institute for the Languages of Finland and Eesti Keele Instituut. 
Taylor, John R. 2007. Semantic categories of cutting and breaking: Some final thoughts. - Cognitive Linguistics 18 (2), 331-337. http://dx.doi. org/10.1515/COG.2007.020

Verhagen, Arie 2005. Constructions of Intersubjectivity. Discourse, Syntax, and Cognition. New York: Oxford University Press.

VISK = Auli Hakulinen, Maria Vilkuna, Riitta Korhonen, Vesa Koivisto, Tarja Riitta Heinonen, Irja Alho 2004. Iso suomen kielioppi. [Descriptive Grammar of Contemporary Finnish.] Helsinki: Finnish Literature Society. Also available at http://scripta.kotus.fi/visk/etusivu.php (29.2.2012).

VSS = Kokla, Paul, Helga Laanpere, Mart Mäger, Arno Pikamäe 1988. Virolaissuomalainen sanakirja. [Estonian-Finnish Dictionary.] Helsinki: Finnish Literature Society.

Wierzbicka, Anna 1996. Semantics, Primes and Universals. Oxford: Oxford University Press.

\section{Minna Jaakola}

Helsingin yliopiston suomen kielen, suomalais-ugrilaisten ja pohjoismaisten kielten ja kirjallisuuksien laitos

PL 3

00014 Helsingin yliopisto, Finland

minna.jaakola@helsinki.fi 


\title{
Tiedon rakentaminen tekstissä: kontrastiivinen analyysi viron ja suomen partikkeleista teatavasti ja tiettävästi
}

\author{
MINNA JAAKOLA \\ Helsingin yliopisto
}

Artikkeli tarkastelee viron ja suomen episteemis-evidentiaalisten partikkelien teatavasti ja tiettävästi merkitystä kognitiivisen kielentutkimuksen teoriakehyksessä. Aineistona on noin 700 esimerkin kokoelma, joka on poimittu Kielipankin sanomalehtikorpuksesta sekä Postimees- ja Õhtuleht-sanomalehtien internetsivuilta. Merkitysanalyysi perustuu kognitiivisen kieliopin kuvaukseen adjektiivikantaisista adverbeista relationaalisina predikaatteina, ja tätä jäsennystä käytetään myös kielten välisen vertailun pohjana. Kontrastointi on tehty analysoimalla aineiston esimerkit partikkelin vaikutusalassa olevan tiedon ominaisuuksien perusteella. Partikkelien teatavasti ja tiettävästi kannalta keskeiset jäsennykset ovat tiedon spesifisyys ja geneerisyys, tiedon konventionaalisuus ja ei-konventionaalisuus sekä tiedon varmuuden ja kiistämättömyyden aste. Suomen partikkelin vaikutusalassa on tyypillisimmin spesifi ja ei-konventionaalistunut tieto. Viron partikkelilla on laajempi käyttöala, ja se esiintyy tasaisemmin sekä spesifin että geneerisen tiedon sekä ei-konventionaalisen kuin myös konventionaalistuneen tiedon yhteydessä.

Molemmat partikkelit ovat tiedon alkuperän suhteen epäspesifejä. Evidentiaalinen epäspesifisyys toteutuu kuitenkin eri tavalla ja aiheuttaa eroja myös partikkelien kantamaan episteemiseen modaalisuuteen. Suomen tiettävästi tyypillisesti implikoi tiedon olevan toisen käden tietoa, ja referointimerkityksen pohjalta partikkelilla voi tuottaa kaksi päinvastaista episteemistä tulkintaa: tiedon varmuutta ilmaisevan ('saadun tiedon mukaan') tai varauksen merkityksen ('niin paljon kuin saadun tiedon perusteella tiedetään'). Sanomalehtiaineistossa sen voi vain harvoin tulkita ilmaisevan neutraalisti tiedon jaettuutta ('kuten tiedetään'). Konventionaalisen ja kiistämättömän tiedon yhteydessä tiettävästi kirvoittaa helposti affektisia ja ironisia tulkintoja, ja myös tällaiseen tietoon liittyvä partikkelin käyttö on sanomalehtiaineistossa marginaalista. Partikkelin tärkein 
tekstiä jäsentävä funktio on implikoida näkökulman jonkinlaista muutosta tai ilmaista referointilinjasta poikkeavaa ääntä.

Viron teatavasti ilmaisee kirjoittajan tarjoavan tietoa varmana ('kuten tiedetään'). Se ei implikoi referointia, eikä se ilmaise kirjoittajan asettamaa varausta tiedon varmuuteen. Aineistossa sitä käytetään sekä konventionaalisen että eikonventionaalisen tiedon yhteydessä, ja kummassakin tapauksessa partikkelin käytön keskeisin funktio on merkitä eksplisiittisesti, että tieto on jaettavissa olevaa ja lukijalla on siihen pääsy. Viron partikkelilla on korosteisesti tekstuaalinen funktio, sillä sitä käytetään usein eksplikoimaan tekstin elementtien etu- ja takaalaisuussuhteita. Teatavasti-lause toimii tyypillisesti taustoittavana tietona, jota tekstissä voidaan käyttää esim. muistutuksena tai perusteluna. Se voi myös asettua osaksi retorista rakennetta, jossa sillä merkitään vertailun toinen osapuoli.

Uutiskontekstissa epäspesifin lähteen ilmauksissa suomen partikkelia voi viroksi vastata teatud andmetel. Luonteva käännös virosta suomeen syntyy usein liitepartikkelilla $-h A n$. Tämän aineiston perusteella erityisesti viron ja suomen evidentiaalisten strategioiden vertailu osoittautuu relevantiksi jatkotutkimuksen aiheeksi.

Avainsanat: episteeminen modaalisuus; evidentiaalinen modaalisuus; relationaalinen predikaatti; intersubjektiivisuus; kogntiivinen kielioppi 